\title{
The Role of BUMKam to rebranding palm sugar products in village of Sakaq Tada, regency of West Kutai
}

\author{
Agung Sugeng Widodo ${ }^{1, *}$, Arik Prasetya ${ }^{2}$, Dhanny Septimawan Sutopo $^{3}$, Darmawan \\ Saptadi $^{4}$, and Mahmuddin Ridlo ${ }^{5}$ \\ ${ }^{1}$ Department of Mechanical Engineering, University of Brawijaya, Malang, Indonesia \\ ${ }^{2}$ Department of Science Business Administration, University of Brawijaya, Malang, Indonesia \\ ${ }^{3}$ Department of Sociology, University of Brawijaya, Malang, Indonesia \\ ${ }^{4}$ Department of Agrotechnology, University of Brawijaya, Malang, Indonesia \\ ${ }^{5}$ Institution of Research and Community Service, University of Brawijaya, Malang, Indonesia
}

\begin{abstract}
Village-owned enterprises have a strong role in rebranding superior village products to increase people's income and employment. Researcher of Doktor Mengabdi (DM) Program from the University of Brawijaya has entered the 5th year of the 2017-2021 activity roadmap in Sakaq Tada Village, Mook Manaar Bulatn District, West Kutai Regency. In the 5th year, the DM team focused their activities on rebranding BUMKam palm sugar processed products to accelerate the industrialization of superior products in West Kutai Regency. Palm sugar is a superior regional product in West Kutai Regency. The sub-districts with the highest sugar palm commodities in West Kutai Regency are Barong Tongkok at 9.44 tons/year, Peninggahan at 7.24 tons/year, and Mook Manaar Bulatn at 6.92 tons/year. Mook Manaar Bulatn District can develop as a superior product of regional palm sugar in the long term with a large plantation area. BUMKam Sakaq Tada, as a distributor, accommodates palm sugar from farmers, then packaging and sales are carried out with the planned consumer net strategy. BUMKam Sakaq Tada needs to synergize with various stakeholders to maximize the marketing and distribution of palm sugar products
\end{abstract}

\section{Introduction}

The villages in the border areas are worrying. Based on the 2015 Developing Village Index (IDM) size, the number of villages on the border that have the status of being left behind and very underdeveloped is very dominant [1]. The average Building Village Index (IDM) for border villages is 0.498 , while the national average IDM is 0.566 . This situation illustrates the level of welfare of the border village, which is still low [2]. The development of the agro-industry and tourism sectors is still a priority in almost every region [3]. West Kutai Regency area has the potential of natural resources supported by land and climate

\footnotetext{
*Corresponding author: agung sw@ub.ac.id
} 
conditions conducive to agricultural development [4]. The agricultural sector is an important sector that can boost economic growth [5]. Local Autonomy Law from the local government needs to develop and participate in the growth of their districts as part of national developments by exploring and utilizing their potential and empowering the community as a part of the economic development [6].

West Kutai Regency is one of the administrative areas in East Kalimantan Province. The West Kutai Regency area has the potential for natural resources supported by land and climate conditions that are conducive to agricultural development [7]. Mook Manor Bulatn District is one of the administrative areas in the West Kutai Regency, which has the potential to develop sorghum and sugar palm plantations [8]. Research activities and community service can be focused on the agricultural sector, where the agricultural industry is the basis that can be developed in Mook Manor Bulatn District. [9]. Sakaq Tada Village, one of the villages assisted by the Doktor Mengabdi (DM) Universitas Brawijaya in 2019 on the process of palm sugar. This is expected to be a solution to develop the human resources to improve the sustainable economic growth of Sakaq Tada villagers [10].

Village funds finance the management of BUMKam as initial capital for development, which can be independent and even increase village income [11]. The initial purpose of establishing BUMKam was to encourage or accommodate all activities to increase people's income [12]. Management of a business must be carried out properly so that BUMKam as a community business institution can develop, one of which is preparing a business plan [13]. Making visions, missions, strategies, and business plans related to the management of BUMKam is carried out to explore the economic potential that exists in the Village and District [14]. In general, natural resource management carried out by an indigenous community recognizes various statuses of control and utilization [15]. BUMKam plays a very important role in driving the community's economy. The government recommends that it be aimed at the human resource development sector [16].

Branding has the word Brand, usually assumed to be the logo of a product, agency service, and others [17]. Branding with an image that is in accordance with the spirit of the product will produce loyal brand consumers. Building a brand can be likened to establishing heart-to-heart communication [18]. The process of making palm sugar is still traditional in West Kutai Regency. The equipment used and processing methods are still simple and traditional [19]. The indicator of the success of making palm sugar starts from the good quality of the palm tree. Taking the best quality palm sap requires several stages, starting from selecting a good parent tree as a source of raw materials, the preparation process for tapping, tapping, storing, cooking, and packing [20]. Farmers in West Kutai Regency mostly take palm sap water as well as cook it into palm sugar. In a day, palm sugar farmers carry out sap every morning and evening [21].

The potentials of the Mook Manoor Bulatn area is the development of a palm sugar industrial center. The embryo pioneer of the palm sugar industry center and other products is expected to grow as an industrial cluster center in the West Kutai Regency area. The community's economic recovery during the Covid-19 pandemic needs to be carried out to maintain social and economic stability. The scope of research from DM activities in 2021 consists of strengthening palm sugar productivity through maximizing BUMDes as initiation of rural-based industrialization embryos in Sakaq Tada Village. The purpose of this research in the West Kutai Regency is to rebrand palm sugar products through online promotion, appropriate technology, and a palm sugar business unit business plan for BUMKam Sakaq Tada. The research from the DM program assists managers/directors in preparing a good vision, mission, and business plan in the short and long term so that the preparation can meet the requirements of a good program conceptually. 


\section{Materials and method}

The long-term plan for implementing the DM research is to make Regional Superior Products a sector of industrialization that strengthens the economy of the village community in the West Kutai Regency. This acceleration requires cooperation between Brawijaya University and the local West Kutai Regency Government. In addition, the main role is the community's proactiveness in this empowerment program.

\subsection{Research stage}

The strategy formulation is a statement that explains how to achieve the goals and objectives, further clarified with a series of policy directions. The stages of research offered through the DM Program of Brawijaya in West Kutai Regency are the rebranding of palm sugar processed products as an acceleration of the industrialization of superior products in West Kutai Regency by strengthening the potential of supporting resources in the area. Based on the Focus Group Discussion (FGD) by the University of Brawijaya DM team and activity partners, in this case, Sakaq Tada Village, West Kutai Regency, it was agreed that the following stages of activities were agreed:

a. Online Promotion

b. Appropriate Technology

c. Strengthening BUMKam as a distributor of palm sugar products

The implementation of the DM research in Mook Manaar Bulatn District in 2021 is carried out in several stages. The focus of DM research in 2021 is on three crucial sectors to be prioritized: agricultural, industrial, and tourism. During the Covid-19 pandemic, whose expiration date is still unknown, superior products produced by the community were experiencing problems in the marketing sector. The DM team will try to connect several partners who can be used as markets for West Kutai's superior products, such as the souvenir center, local government galleries, local communities.

The rebranding was carried out to strengthen the marketing of the superior product of the West Kutai area, namely palm sugar. Website and social media function as information systems or marketing media for superior products and promotion of tourist attractions that are an attraction in the West Kutai area. In addition to palm sugar products, websites and social media can be used for marketing other superior products, namely rattan handicrafts, West Kutai batik, langsat fruit, and durian fruit. With the DM program, the surrounding community becomes productive, creative, adds jobs, improves the economy and community welfare.

\subsection{Roadmap of DM research}

The sustainability of the DM research is in the form of product development and superior tourism potential in the West Kutai area. From 2017-2018, DM research has been carried out in Tende Village as the priority of 40 pilot villages pioneered by the Ministry of Research, Technology, and Higher Education. The identification and solution of the problem have been conveyed by the development of the potential of rattan woven crafts and the development of a distinctive culture in the area. In 2021, the DM research proposed a series of community service activities related to the marketing strategy of superior regional products in the Mook Manaar Bulatn area. BUMKam has a major role in marketing regional superior products. The role and support of relevant stakeholders are needed in marketing superior products and tourism in the Regency of West Kutai, Province of East Kalimantan. 


\section{Results}

Mook Manaar Bulatn sub-district has a huge potential for agricultural commodities to improve the community's economy. The existence of BUMKam and other community institutions that have been formed are expected to move the economy of the Mook Manaar Bulatn District, West Kutai Regency. In 2021, the DM research proposed a series of activities related to the marketing strategy of superior regional products in the Mook Manaar Bulatn area. BUMKam in the Mook Manaar Bulatn District has a major role in marketing regional superior products. The role and support of relevant stakeholders are needed to successfully market superior tourism and products in West Kutai Regency. Focus Group Discussion (FGD) between Brawijaya University and Sakaq Tada Village has been carried out, as shown in Figure 2.

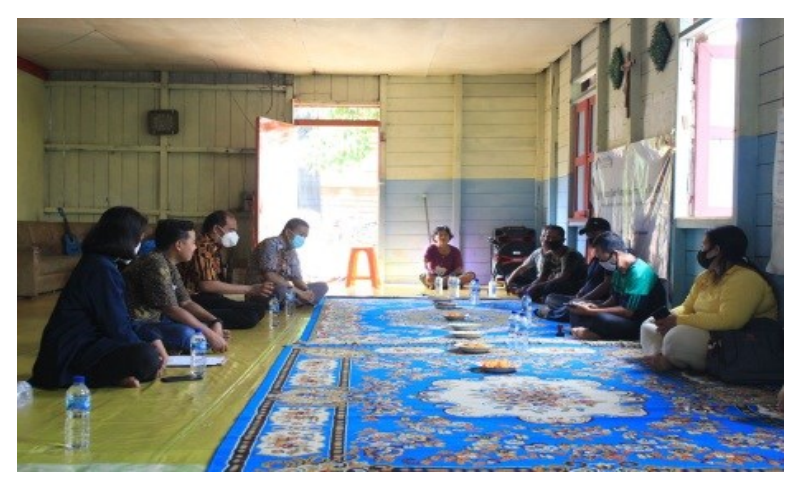

Fig. 1. FGD activities of the Brawijaya University DM team in Village of Sakaq Tada,

\subsection{Online promotion}

The potential for palm sugar is very high in the Mook Manaar Bulatn District, especially in Sakaq Tada Village. Some palm sugar processing SMEs have even received halal certification. However, the quality of the product decreases. The low quality of products processed by farmers triggers palm sugar middlemen to suppress the selling price of the product. In addition, the products processed by farmers are still semi-finished, so they need to be further processed to be packaged properly. The low selling price of the product is because farmers cannot directly penetrate the market, so prices are controlled by middlemen as collectors of processed farmers' products. As a solution, the DM and KKN team initiated palm sugar promotion media in the form of websites. With this promotional media (Fig. 3), BUMKam, a distributor of palm sugar products, can reach wider market segments in regional and national areas.

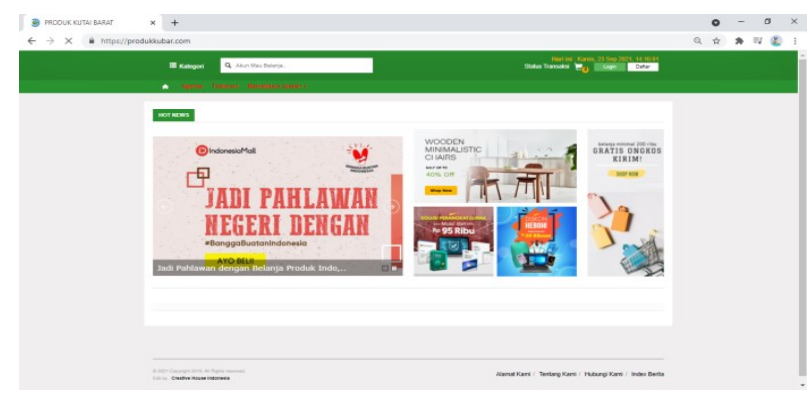

Fig. 2. BUMKam's website as marketing media for superior products 


\subsection{Appropriate technology}

The potential of the plant and the production of sugar palm in the village of Sakaq Tada has developed well. In addition, there have been several palm sugar craftsmen with various sugar products. However, palm sugar processing by farmers is still very limited in the production process, equipment, and product standards produced. In addition, he also pays attention to the cleanliness of the palm sugar and palm sugar production room. In 2021, the DM research will provide assistance in distributing palm sugar for BUMKam Sakaq Tada. One of the product innovations carried out is the diversification of palm sugar products by mixing several spices, such as ginger and turmeric. A blender in refining the spices is needed so that that palm sugar products can be accepted by the consumer market. The DM team gave two blender units to BUMKam, which could be used as a palm sugar processing unit. Figure 4 . below is the delivery of 2 blender units by the DM team to the partner of BUMKam Sakaq Tada.

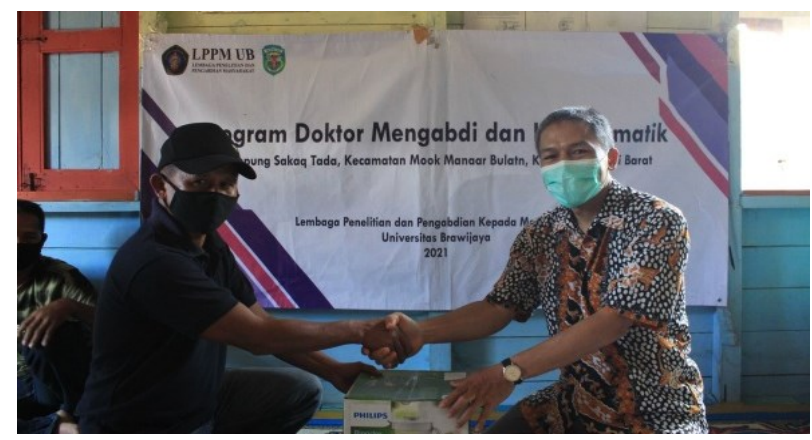

Fig. 3. Giving of 2 blender units from the DM research to BUMKam Sakaq Tada

\subsection{Strengthening BUMKam as a distributor of palm sugar products}

The mindset of farmers in palm sugar processing is still limited to cooking with makeshift stoves and fuel in the form of wood from forest products. In addition, the process of printing palm sugar is still very simple without any definite standards. BUMKam Sakaq Tada, as a distributor, accommodates palm sugar from farmers, then packaging and sales are carried out with the planned consumer net strategy. Palm sugar marketing strategy with strengthening BUMKam as a distributor of palm sugar products. BUMKam Sakaq Tada needs to synergize with various stakeholders to maximize the marketing and distribution of palm sugar products. So far, the development of BUMKam is still constrained by many things, starting from the lack of knowledge about the functions and objectives of BUMKam. BUMKam in Mook Manaar Bulatn District has not been managed properly, and there is still a lack of support from Experts.

Institutional strengthening of BUMKam Sakaq Tada serves as a potential development for the palm sugar industry, batik, rattan woven crafts, and agricultural commodities. The selection of the BUMKAM institution was based on the consideration of the central role of the local institution in increasing the added value of the village community's plantation sector. BUMKam was established to encourage and accommodate all community economic activities in order to increase people's income, both those that develop according to local cultural customs and community economic activities whose management is handed over to the community through government programs/projects. Figure 5 below shows the activities of the DM team and KKN students in strengthening BUMKam as a distributor of palm sugar products in Sakaq Tada Village, West Kutai Regency. 


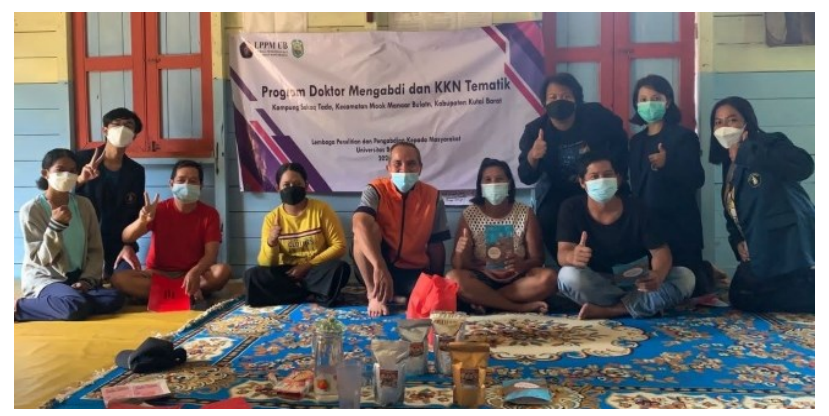

Fig. 4. The assistance of BUMKam Sakaq Tada as a distributor of palm sugar products

Local institutions regarding the management and utilization of natural resources in various communities are systematic and holistic, where human existence is seen as not separate from and above nature but as an integral part that cannot be separated from and integrated with nature. The multidimensional ecological approach does not only take into account economic aspects and benefits but also various aspects of other dimensions. Regional superior products need to be supported by the standardized product quality and attract consumers. The role of BUMKam is maximized as an effort to strengthen the sugar palm plantation sector from the local government through local institutions. The results of palm products in the form of juice from farmers and palm sugar from craftsmen will be purchased by BUMKam, which will then distribute these products to markets and large industries. The role of BUMKam is vital for sugar palm farmers to protect their products from price pressures and middlemen.

\section{Conclusion}

The implementation of the DM research in West Kutai in 2021 is carried out in several stages, namely online promotion, appropriate technology, and business plan of palm sugar for BUMKam Sakaq Tada. DM research initiated palm sugar promotion media in the form of websites and Instagram. With this promotional media, BUMKam, a distributor of palm sugar products, can reach wider market segments in regional and national areas. A blender in refining the spices is needed so that that palm sugar products can be accepted by the consumer market. The DM team gave two blender units to BUMKam, which could be used as a palm sugar processing unit. BUMKam Sakaq Tada, as a distributor, accommodates palm sugar from farmers, then packaging and sales are carried out with the planned consumer net strategy. Palm sugar marketing strategy with strengthening BUMKam as a distributor of palm sugar products. BUMKam Sakaq Tada needs to synergize with various stakeholders to maximize the marketing and distribution of palm sugar products.

\section{References}

1. N. Hidayat, C. Dewi, N.F. Nuzula, Senoaji, Journal of Food and Life Sciences, 2 (2), 89 - 93, (2018)

2. Kemendesa PDTT RI, Building Village Index, Kemendesa PDTT RI, Jakarta, (2015)

3. A.M. Ahmad, Susenohaji, D.Y. Ali, M.E. Arief, A. Fibrianingtyas, Postharvest Handling of Soursop Fruit and Optimization of Soursop Product Marketing in Wonorejo Trisulo Village, Plosoklaten District, Kediri Regency, Proceedings of the 
National Seminar and Call for Paper 2018. Faculty of Economics and Business, University of Lampung, pp 7-12, (2018)

4. S. Wijana, A.S. Widodo, B.S. Haryono, D.S. Sutopo, Mapping the Potential of Tende Village, Bentian Besar District, West Kutai Regency, East Kalimantan, Proceedings of the Seminar on Community Service Results (SNP2M), pp.310-315, (2017)

5. A.S. Widodo, S. Wijana, D.S. Sutopo, I.A. Dewi, N.A. Rohmanna, Development of Tende Village, Bentian Besar, West Kutai Towards a Craft-Based Empowerment Village in the Border Area, Proceedings of the Seminar on Community Service Results (SNP2M), pp.422-427, (2018)

6. V. Tamaya, S. Sulandari, L. Dyah, Optimizing Batik Village in Developing Semarangan Batik Industry in Semarang City, Journal of Universitas Diponegoro, 114, (2012)

7. BPS of West Kutai, West Kutai Regency Gross Regional Domestic Product by Expenditure, West Kutai, (2019)

8. S. Hartini, The Diversity of Flora from the Natural Monument of Kersik Luway, East Kalimantan, Biodiversitas, 8 (1), 67-72, (2007)

9. S.A. Danarto, The role of local communities in orchid conservation: A case study in Kampung Empas, West Kutai, East Kalimantan, Proceedings of the Indonesian Biodiversity Society Seminar, 5 (2), 199-204, (2019)

10. AS. Widodo, S. Wijana, D.S. Sutopo, H.Y. Setyawan, Batik Empowerment for Sakaq Tada Village Community, Manor Bulatn, West Kutai, East Kalimantan. Proceedings of the Seminar on Community Service Results (SNP2M), 76-79, (2020)

11. G. Irianto, S.P. Prabandari, Z.P. Gama, M.S. Hadi, M. Jamroni, M. Ridlo, Initiation and Assistance of Bumdes as Embryo of Community Economic Improvement in Bocek Village, Karangploso, Malang. Proceedings of the 4th National Seminar on Research \& Community Service, 544-551, (2020)

12. D. Wijaya, BUM Desa : Village Owned Enterprises. Gava Media, Yogyakarta (2018)

13. Defrizal. Strategic Management and Business Planning for Village-Owned Enterprises (BUMKam) and Inter-Village-Owned Enterprises (Bumkam) in Tulang Bawang Regency, Lampung Province. Lampung, (2016)

14. S. Efendi, Village Owned Enterprise Development Strategy by the Rajadesa Village Government, Rajadesa District, 6 (4), (2019)

15. A.S.K. Dewi, The Role of Village Owned Enterprises (BUMDes) as an Effort in Increasing Village Original Income (PADes) and Growing the Village Economy, Journal of Rural and Development, 5 No.(1), 1-13, (2014)

16. Ministry of National Education Center for the Study of Development System Dynamics (PKDSP), Guidebook for Establishment and Management of Village Owned Enterprises (BUMDes), Surabaya, Faculty of Economics, Universitas Brawijaya, (2007)

17. S. Rustan, Logo Design. PT Gramedia Pustaka Utama, (2019)

18. D. Redono, Simple Promotion and Branding for Small and Medium Enterprises. UB Press, Malang. (2013)

19. Center of Statistics Agency, Mook Manaar District Round in Figures 2019. West Kuta, (2019)

20. R. Antomi, S. Balkis, Financial Aspects of Palm Sugar Business with Agroforestry System in Samboja District, Kutai Kartanegara Regency, Journal of Tropical Forestry Humida, 4 (2), 161-172, (2011) 
21. Bappeda, West Kutai Regency, Study on Development of Palm Sugar Industry Potential and Handling of Rubber Raw Materials Based on BUMKAM in West Kutai Regency, East Kalimantan Province, Report on Cooperation Agreement between Bappeda Kutai Barat and Universitas Brawijaya, (2019) 